Mr. George Scott Robertson spoke on "A Comparison of the Effect of Various 'Types of Open Hearth Basic Slags on Grassland."

\title{
A COMPARISON OF THE EFFECT OF VARIOUS TYPES OF OPEN HEARTH BASIC SLAGS ON GRASSLAND.
}

\author{
By George Scott Robertson, M.Sc.
}

In a paper read to the Society of Chemical Industry in January, $1916, *$ the writer drew attention to the large quantities of opea hearth basic slag then being produced on Tees-side. It was pointed out that little, if any, of this basic slag found its way on to the agricultural market, largely on account of the low solubility of the phosphate according to the then official citric acid test, $\downarrow$ and partly, though to a much less extent, on account of the lower percentage of phosphoric acid which it contained. The low solubility of these open hearth basic slags (only 20-50 per cent. of the phosphoric acid was soluble, according to the citric acid test, compared with 80-90 per cent. of the higher grade basic Bessemer slags) was shown to be due to the fluorspar which it was necessary to introduce into the furnace during the manufacture of steel by the basic open hearth process in order to secure a readily fusible slag.

Attention was moreover directed to the fact that such open hearth basic slags were the outcome of a different process of manufacture, resulting in the production of a type of phosphate similar to that in mineral phosphates, $t$ and that whatever significance the citric acid test as then practiced had, the altered conditions of manufacture entirely destroyed it.

Continuous extractions with the official citric acid solution demonstrated that the test by no manner of means gave a fair representation of the solubility of the phosphoric acid in open hearth basic slag, and cases were cited where a second extraction brought considerably more phosphoric acid into solution than was obtained in the first extraction. Even two extractions did not suffice to bring all the citric soluble phosphoric acid into solution, and it was demonstrated that if four or five half hour extractions were made, practically all the phosphoric acid in these slags could be dissolved by the weak citric acid solution.

Solution of the phosphoric acid in the soil is a continuous process, and it was argued from these laboratory experiments that the citric acid test was not a correct criterion of the agricultural value of these open hearth basic slags.

* Journ Soc. Chem. Ind., Vol. XXXV., p. 216.

† To perform this test $5 \mathrm{gms}$ of the phosphate is placed in a litre flask containing $500 \mathrm{cc}$. of $2 \%$ citric acid solution. The flask is shaken end over end for 30 minutes in an apparatus making 30 revolutions per minute

$\ddagger$ Journ. Agric. Science, Vol. VIII, p. 1 


\section{A COMPARISON OF THE EFFECT OF VARIOUS TYPES}

In order to test these deductions three field experiments were started on old grass land in Essex during the winter of 1915, and subsequently several other centres during 1916,1917 and 1913. Three types of soil were selected, namely, the London clay, Boulder clay, and the Chalk soils. Quarter acre plots were marked off and the phosphates applied at a standard rate of $200 \mathrm{lbs}$. of phosphoric acid per acre.

The fields selected had not received artificial manures for at least twenty to thirty years previously, and since the application of the various types of phosphate, when the experiments commenceri no further dressings of any description have been applied.

Chemical examination showed that all the soils save one were very deficient in total phosphoric acid, that all were deficient in available phosphoric acid, and that only one, the chalk soil, contained an adequate supply of calcium carbonate. The figures are set out below.

TABLE I.

Partial analysis of the soils at the various experimental centres.

\begin{tabular}{|c|c|c|c|c|c|c|}
\hline & \multicolumn{3}{|c|}{ BOULDER CLAY. } & \multicolumn{2}{|c|}{ LONDON CLAY. } & \multirow{2}{*}{ WHALK } \\
\hline & $\begin{array}{l}\text { Tysea } \\
\text { Hili. }\end{array}$ & $\begin{array}{l}\text { Martins } \\
\text { Hearne }\end{array}$ & $\begin{array}{l}\text { Farn- } \\
\text { ham. }\end{array}$ & $\begin{array}{c}\text { Latching- } \\
\text { don }\end{array}$ & $\begin{array}{l}\text { Horn- } \\
\text { don. }\end{array}$ & \\
\hline $\begin{array}{l}\text { Phosphoric acid (sol. in } \\
\text { strong } \mathrm{H} \mathrm{Cl.)} \mathrm{...}\end{array}$ & $\begin{array}{c}\% \\
.101\end{array}$ & $\begin{array}{c}\% \\
.089\end{array}$ & $\begin{array}{l}\% \\
.118\end{array}$ & $\begin{array}{c}\% \\
.077\end{array}$ & $\begin{array}{c}\% \\
.078\end{array}$ & $\begin{array}{c}\% \\
.210\end{array}$ \\
\hline \begin{tabular}{ccc} 
Available & \multicolumn{2}{r}{ Phosphoric } \\
$\operatorname{acid}$ & $\ldots$ & $\ldots$
\end{tabular} & .0051 & .0046 & .0067 & .0066 & .0030 & .0013 \\
\hline Calcium Carbonate & 0.00 & 0.00 & 0.46 & 0.37 & 0.25 & 36.30 \\
\hline Lime requirement & 0.29 & 0.27 & 0.00 & 0.05 & 0.00 & 0.00 \\
\hline
\end{tabular}

Considerable difficulty was experienced in 1915 in securing suitable open hearth slags, as none of the steel firms approached were prepared to grind even a limited quantity for experimental purposes. Eventually an open hearth basic slag in which only 45 per cent. of the total phosphoric acid was citric soluble, was secured, and for the later experiments open hearth slags with as low solubilities as 20-30 per cent. were obtained. The collected results from these experiments are given in Table II.

An examination of the results presented in this table indicates that whilst the returns from the various open hearth basic slags are somewhat erratic when contrasted with basic slags of high citric solubility, they have nevertheless given in every case highly profitable returns. In each experiment the open hearth basic slag of 45 per cent. solubility has proved to be strictly comparable with the highest citric soluble types of basic slag. On the other hand, the open hearth basic slags with a solubility of from 20-30 per cent. do not, on the whole, do quite so well. At Martins Hearne, for example, the returns are distinctiy inferior to the high citric 
OF OPEN HEARTH BASIC SLAGS ON GRASSLAND 293

soluble slag, although it must be borne in mind that the open hearth basic slag plot would be considered an excellent and highly profitable one compared with the unmanured, were it not for the contrast afforded by both the rock phosphate and the high citric soluble slag plots. (See Fig. 1.)

TABLE II.

\begin{tabular}{|c|c|c|c|c|c|c|c|}
\hline \multirow[b]{3}{*}{$\begin{array}{c}\text { Manures. } \\
200 \text { lbs. } \\
P_{5} O_{8} \text { per acre }\end{array}$} & \multirow{3}{*}{ 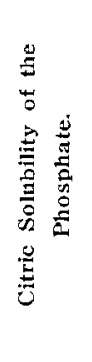 } & \multicolumn{5}{|c|}{ Hay, Cwts. per acre. } & \multirow{3}{*}{ 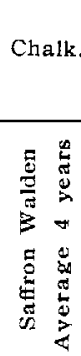 } \\
\hline & & \multicolumn{2}{|c|}{ Boulder Clay's. } & \multicolumn{3}{|c|}{ London Clay. } & \\
\hline & & 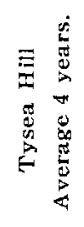 & 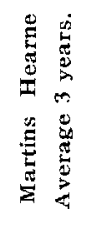 & 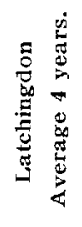 & 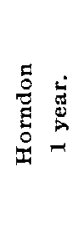 & 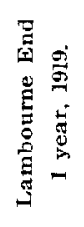 & \\
\hline High Grade Basic Slag & 92. & 30.9 & - & 31.7 & - & - & 41.2 \\
\hline Gafsa Rock Phosphate & 38. & 30.5 & 29.1 & 29.7 & $23.0^{*}$ & $25.0 \dagger$ & 38.7 \\
\hline No Manure $\ldots \quad \ldots$ & - & 20.3 & 16.0 & 21.7 & 15.5 & 13.2 & 31.1 \\
\hline $\begin{array}{r}\text { Open Hearth Fluorspar } \\
\text { Basic Slag (1) }\end{array}$ & 45 & 32.8 & - & 30.8 & - & - & 40.0 \\
\hline do. do. (2) & 20 & - & 22.7 & - & 18.8 & 26.6 & - \\
\hline do. (3) & 32 & - & - & - & - & 16.0 & - \\
\hline $\begin{array}{r}\text { Low Grade High Citric } \\
\text { Sol. Basic Slag (1) }\end{array}$ & 93 & 32.8 & - & 31.6 & - & -- & 35.2 \\
\hline do. do. (2; & 82 & 32.3 & -- & 33.9 & - & - & 40.2 \\
\hline do. do. (3) & 91 & - & 30.2 & - & 22.5 & 24.5 & - \\
\hline do. do. (4) & 80 & - & - & - & - & 23.7 & - \\
\hline $\begin{array}{c}\text { Average Rainfall, } 1 \text { st } \\
\text { May till Harvest }\end{array}$ & & 4.66 & 6.91 & 4.88 & 2.25 & 3.26 & 2.74 \\
\hline $\begin{array}{l}\text { do. 1st April } \\
\text { till Harvest } \\
\text { (inches) }\end{array}$ & & 7.02 & 9.35 & 7.11 & 4.64 & 6.46 & 5.26 \\
\hline
\end{tabular}

* Egyptian Phosphate.

† Cambridge Coprolites.

A great deal of stress cannot be placed upon the one year's hay returns at Horndon. Circumstances prevented the sowing of the manures on the plots till February $27 \mathrm{th}, 1918$, and as the hay crop was cut during the first week of July, the manures had not time enough to produce their maximum effect. During the 1919 season the plots were grazed at this centre by cattle and sheep, and 


\section{A COMPARISON OF THE EFFECT OF VARIOUS TYPES}

the relative effect of the various types of basic slag was judged by their influence on the botanical composition of the flora.

At Lambourne two types of open hearth basic slag of very similar composition and solubility were compared with two low grade slags of high citric solubility. The experiment has as yet only been running for one year, but as the response to phosphates during the dry season of 1919 is very marked, the results are not without significance. An open hearth slag plot is always next to a high citric soluble slag plot, so that the risk of soil variations interfering with the results has been reduced to a minimum. Open hearth basic slag 2 is next to high citric soluble slag 3 , and it will be seen that open hearth basic slag 2 gives slightly superior results. On the other hand, however, open hearth basic slag 3 and high citric soluble basic slag 4 are also next to each other, but in this case the high citric soluble slag is much superior. Open hearth basic slag 3 shows a very poor return for the first year at any rate.

On soils well supplied with calcium carbonate, the low citric soluble phosphates do as well as the high citric soluble basic slags in the wetter seasons, but they do not do so well during the drier seasons. On acid soils low citric soluble phosphates appear to do quite as well as the high citric soluble phosphates in dry and in wet seasons.

It is not infrequently remarked by farmers that the basic slag of to-day is not so good as the "old slag." In the writer's experience, however, this opinion is largely due to it not being sufficiently realised that the "new" open hearth basic slags contain only from 18-26 per cent of phosphate, compared with 36-44 per cent. in the high grade basic Bessemer slags. Many farmers, when applying basic slag, pay little attention to its phosphate content, and work on the principle of applying 3.5 cwt. for a cereal or root crop and 5-7 cwts. on a meadow, irrespective in many cases of the grade of the slag.

\section{Effect of Open Hearth Basic Slag on Pastures.}

The great value of hasic slag on pastures is largely due to its effeet in encouraging the growth of clovers, particularly wild white clover. On the heavier soils poor pastures, consisting chiefly of coarse grasses and weeds without any visible signs of clover, may in the course of a year to eighteen months be transformed into first class pastures covered with a luxuriant bottom of wild white clover as a result of a liberal dressing of phosphoric acid in the form of basic slag. Wild white clover is a bottom clover, and it seldom gets into the hay cut in Essex. For this reason, therefore, the increased weight of hay is not an adequate measure of the improvement produced by the application of slag. Whilst the hay crop may be doubled on the slag plots, feeding trials would in all probability show from three to six times greater returns on the slagged plots than on the unmanured.* Unfortunately, with the facilities avail. able it has not been possible to conduct grazing trials. The plots on two of the experimental centres have, however, been grazed with

- Guide to Cockle Park, 1917 page 14. 
cattle and sheep at Farnham for two seasons and at Horndon for one season. During August and September, 1919, determinations of the area occupied by the various types of vegetation were made by the method recommended by Armstrong. ${ }^{*}$ The results are set out in the following tables:-

TABLE III.

\begin{tabular}{|c|c|c|c|c|c|c|}
\hline \multirow[b]{2}{*}{$\begin{array}{c}\text { Type of } \\
\text { Vegetation. }\end{array}$} & \multicolumn{3}{|c|}{ Farnham (Boulder Clay Soil). } & \multicolumn{3}{|c|}{ Horndon (London Clay Soil). } \\
\hline & $\begin{array}{c}\text { Plot 1. } \\
\text { Open hearth } \\
\text { Basic Slag } \\
\text { (Solubility } \\
\left.20^{\circ}\right) .\end{array}$ & $\begin{array}{c}\text { Plot } 2 . \\
\text { High Citric } \\
\text { Soluble } \\
\text { Basic Slag } \\
\text { (Solubility } \\
\text { 91/ }\end{array}$ & $\begin{array}{c}\text { Plot } 3 . \\
\text { No } \\
\text { Manure. }\end{array}$ & $\begin{array}{c}\text { Plot 18. } \\
\text { Open hearth } \\
\text { Basic slag } \\
\text { (Solubility } \\
20^{\circ} \text { ). }\end{array}$ & $\begin{array}{c}\text { Plot 17. } \\
\text { High Citric } \\
\text { Soluble } \\
\text { Basic Slag } \\
\text { (Solubility } \\
\left.91^{\circ}\right) .\end{array}$ & $\begin{array}{l}\text { Plot } 16 . \\
\text { No } \\
\text { Manure. }\end{array}$ \\
\hline Clovers $\ldots$ & $\begin{array}{c}\% \\
27.1\end{array}$ & $\begin{array}{c}\% \\
50.2\end{array}$ & $\begin{array}{c}\% \\
16.2\end{array}$ & $\begin{array}{c}\% \\
43.8\end{array}$ & $\begin{array}{c}\% \\
46.2\end{array}$ & $\begin{array}{l}\% \\
9.4\end{array}$ \\
\hline Grasses ... & 45.0 & 33.3 & 18.4 & 31.8 & 47.2 & 191 \\
\hline Weeds ... & 16.0 & 13.5 & 25.0 & 13.3 & 1.4 & 26.0 \\
\hline Bare Space & 11.9 & 3.0 & 40.4 & 11.1 & 5.2 & 455 \\
\hline
\end{tabular}

Manures sown Feb. 22nd. 1917.

Manures sown Feb. $27: 1,1918$.

There can be ro doubt from a study of Table III. and Fig. 2 that at both centres the application of open hearth basic slag has resulted in a marked improvement in the pasture-and one which is much greater than might have been expected from the low citric solubility of the slag. At neither centre does the open hearth basic slag da quite so well as the high citric soluble basic slag. At Horndon, where the soil is exceptionally poor in total and available phosphoric acid, the difference between the two types of basic slag is not great. At Farnham, where the content of total and available phosphoric acid in the soil is considerably higher, the differences between the two types of slag are more marked. The superior results from the high citric soluble slag at Farnham are largely due to the more even growth of the clover and the absence of comparatively bare spots in this plot. On the open hearth basic slag plot, the clover bottom is less regular and is not so close.

The Relation of Citric Solubility to the Value of the Phosphate.

At Tysea Hill, Latchingdon, and Horndon, there appears to be little or no relation between citric solubility and the increase in hay crop or the improvement of the pasture. At Martins Hearne and Farnham, on the other hand, solubility is of some importance, though in neither case does the citric acid test appear to give a fair or reliable indication of the relative value of the two types of basic slag. The results from the Lambourne experimental centre are more difficult to interpret. An open hearth basic slag of very low solubility, 20 per cent., gives the best results, whilst another of somewhat higher solubility, 32 per cent., gives the poorest results.

\footnotetext{
* Journ. Agricult. Science, Vo\}, II., p. 286.
} 


\section{A COMPARISON OF THE EFFECT OF VARIOUS TYPES}

It is not a question of a difference of a hundredweight or so of hay, but of $10 \mathrm{cwts}$, or, interpreted in percentages, one open hearth slag gives an increase in the hay crop of slightly over 100 per cent., whilst the other only increases the crop slightly over 20 per cent.

It is difficult to resist the conclusion that there is a great difference in the rate at which the phosphoric acid in these two open

\section{Diagram Showing the Percent age of Cround Space Occupied by the Vegetation.}

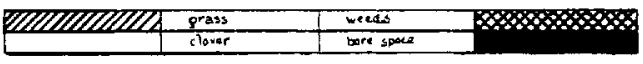

Farnham. Soll: Boulder Clay.
Horndon. Soll: London Clay.

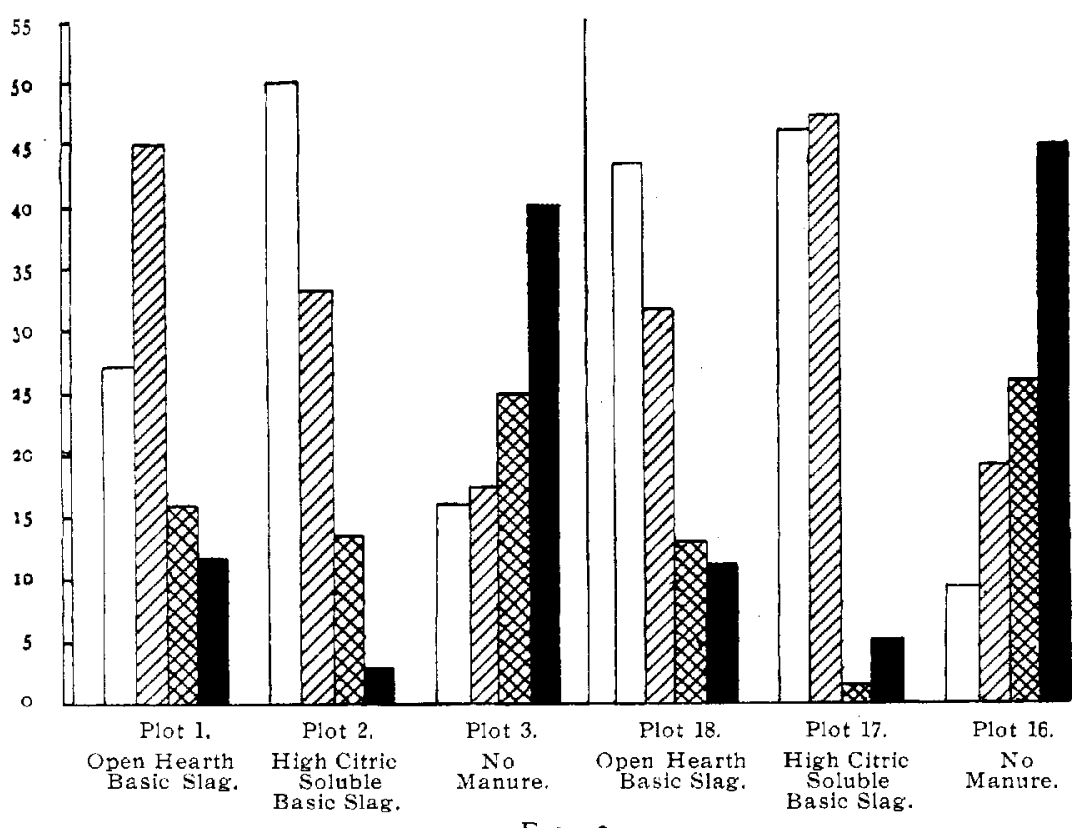

Fig. 2.

hearth slag order to ascertain whether any difference between various open hearth basic slags could be brought out in the laboratory by solution in citric acid, a series of solubility trials were made, using one gramme of slag instead of five, and keeping the remainder of the conditions 


\section{OF OPEN HEARTH BASIC SLAGS ON GRASSLAND 297}

precisely the same as in the official test. In the following table the results for a variety of phosphates are set out and compared with the solubilities according to the old official citric acid test.

TABLE IV

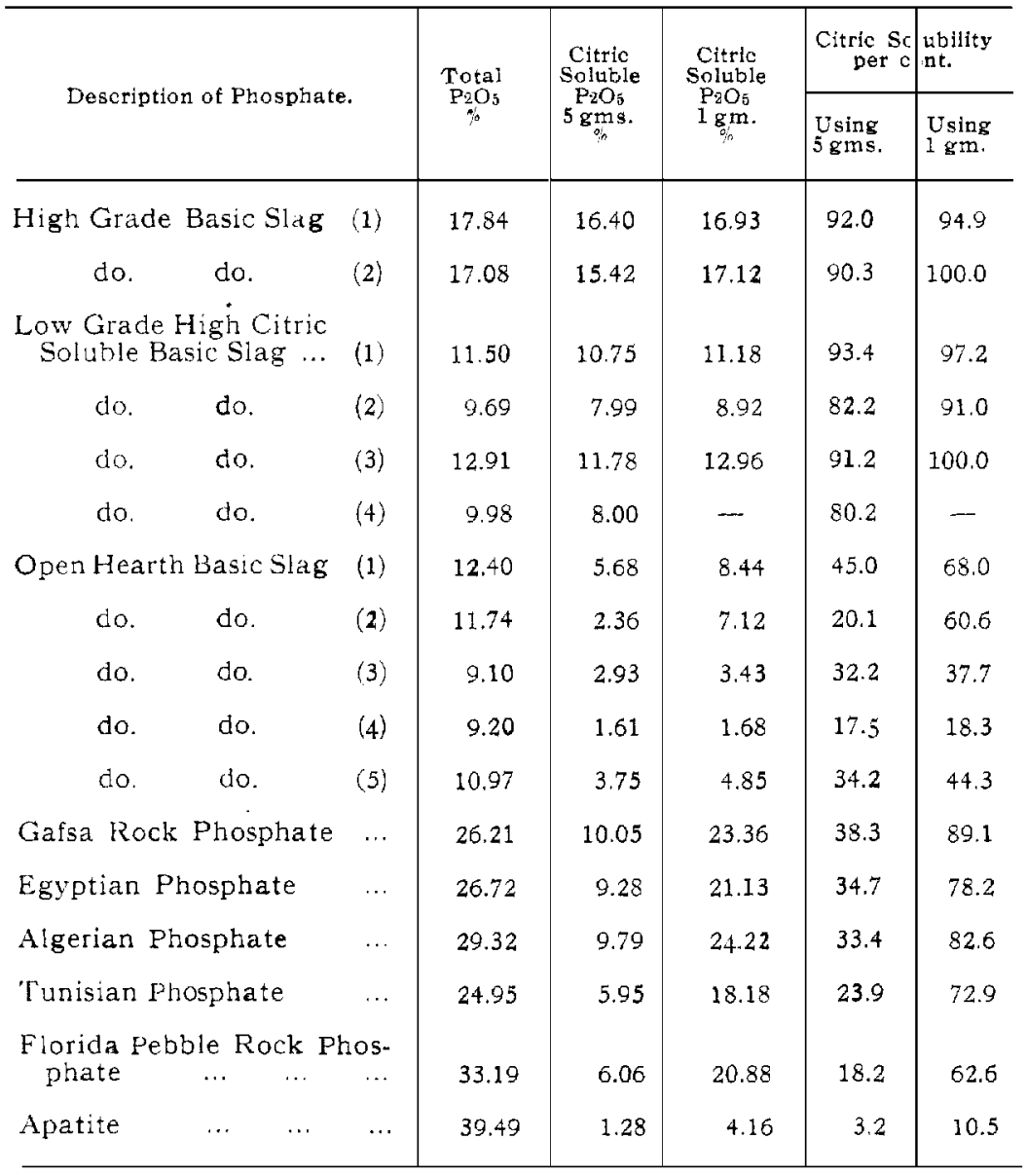

The above table brings out several points of considerable interest. The solubility of high grade basic slags are, as might be expected, not greatly affected by modifying the test, so that one gramme instead of five is shaken for half an hour with 500 c.c. of 2 per cent. citric acid.

The figures for open hearth basic slags and the various rock phosphates afford a striking contrast. Gafsa rock phosphate has now a high percentage solubility, comparable with that of a high grade basic slag, instead of a low one, and it is worthy of note that in the field trials Gafsa rock phosphate proves to be approximately equal to the higher grades of basic slag. The same holds true to a lesser extent with the other types of rock phosphates. 


\section{A COMPARISON OF THE EFFECT OF VARIOUS TYPES}

The modified test b:ings out some curious differences between the various open hearth basic slags. Open hearth basic slags 1 and 2 show a much greater solubility by the modified method; Nos. 3 and 4 , on the other hand, are little affected by the change. Moreover, it is 1 and 2 which do so well in the field trials, whilst No. 3 does badly (see results from Lambourne, Table II).

For the one experimental centre, Martins Hearne, where solubility appears to be of some importance, the average field returns

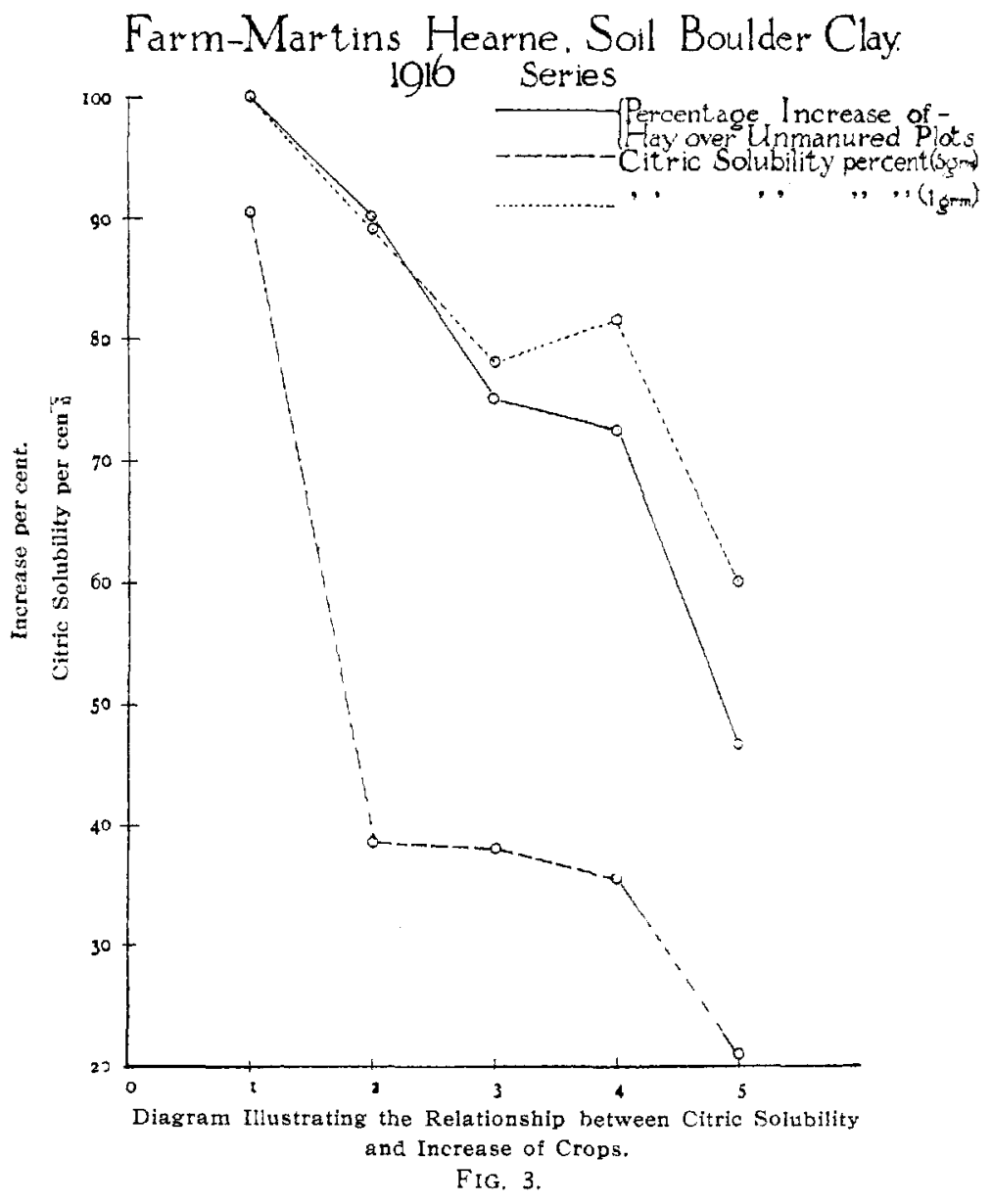

from the various phosphates over a period of three years, the solu. bility of the phosphates, according to the former official citric acid test, and when 1 gramme is used in performing the test instead of 5 , are shown graphically in Fig. 3. The high citric soluble basic slag gave an average increase of 90 per cent. over the unmanured plot. This increase has been taken as 100, and the percentage increase for the other phosphates modified accordingly. Reference to Fig. 3 shows little or no correlation between the field roturns and 


\section{OF OPEN HEARTH BASIC SLAGS ON GRASSLAND 299}

the solubilities of the phosphates according to the old official citric acid test, but there is, on the other hand, a fairly close relationship between the field returns and the solubilities when 1 gramme in. stead of 5 grammes is used in performing the test.

It is not suggested that these results justify the setting up of a new citric acid test. The field trials do, however, show considerable differences in the returns from open hearth basic slags, which have every appearance of being similar. These differences are not brought out by the old official test; in fact, they are sometimes disguised; compare results in Table IV from open hearth basic slags $2,3,4$, and 5 . The modified method does serve to distinguish between these slags.

The information from the field trials is somewhat limited, and it would seem, in view of the facts brought out, very desirable that a number of these open hearth basic slags should be tried at two or three experimental centres where the phosphoric acid content of the soil is low, and the response to phosphatic manuring consequently pronounced.

\section{The Itilisation of the Lower Grades of Open Hearth Basic Slag.}

The majority of the open hearth basic slags at present on the agricultural market contain from 9 to 12 per cent.. of phosphoris acid. There are, however, very large quantities of these slags containing from 5 to 8 per cent. of phosphoric acid, which present conditions make it difficult to market because grinding and freight charges make their cost excessive. At the same time there is a scarcity of phosphates, and the demand by the agricultural community is increasing at a greater rate than supplies are becoming available. If the phosphoric acid content of these lower grade open hearth basic slags could be raised to a level of 10 per cent., it would be possible to market them and thus to no inconsiderable degree relieve the existing shortage. The use of rock phosphates for this purpose has been suggested by Professor Gilchrist, and even prior to 1914 was successfully carried out by several manufacturers. The desirability of such a method of grading up these open hearth basio slags turns upon the extent to which these rock phosphates are comparable with the phosphates in basic slag. Professor Gilchrist's results at Cockle Park, " Professor Hendricks' in Aberdeen, and the writer's results in Essex show that they are but little inferior as a source of phosphoric acid to the higher grades of basic slag. An indication of the Essex results from various rock phosphates is given in Table II by the returns from Gafsa rock phosphate, but they will be dealt with in more detail at a later period. They suffice to show, however, that rock phosphates as a source of phosphoric acid are quite equal, if not superior to open hearth basic slag, so that no objection could be taken to them from this point of view.

There are three ways in which rock phosphates could be used for this purpose:-

1. By addition to the furnace.

2. By addition to the molten slag in the ladle.

3. By grinding and mixing with the ground slag.

* Guide to Cockle Park, 1917, page 34. 


\section{A COMPARISON OF THE EFFECT OF VARIOUS TYPES}

Of the three methods the first is undesirable, as it entails an alteration in the furnace charge, whilst the third method involves two separate grindings if the mixing is to be thorough. The second method avoids the disadvantages of the other two, and is the easiest to manipulate and control.

\section{Conclusions.}

1. The field trials indicate that open hearth basic slags provide a valuable source of phosphoric acid on soils very deficient in this ingredient, and that these slags can be very profitably used for the improvement of our heavy clay soil pastures and meadows.

2. The laboratory and field results both suggest that open hearth basic slag is not a uniform material, and that important differences may exist between two open hearth basic slags of similar solubility. One may succeed, whilst the other produces poor results.

3. Solubility according to the citric acid test is no criterion nor yet an approximate indication of the fertilising value of open hearth basic slags compared with high citric soluble basic slags.

4. It is eminently desirable that several series of field experiments on both arable and grass-land should be carried out over a period of years with as many different types of open hearth basic slags as can be conveniently procured. It cannot be too often emphasised that they contain a new type of phosphate, and much more information than at presents exists is necessary, as well as desirable.

5 . It has often been stated that the foundation of a permanent system of soil fertility depends more than anything else upon an adequate supply of phosphates. In view, therefore, of the increasing agricultural demand for phosphates, it is advisable that consideration should be given to the feasibility of grading up the phosphoric acid content of the lower grades of open hearth basic slags in such a way that it may be economically possible to place them on the agricultural market. 
MARTINS HEARNE.

Soll :-Boulder Clay,
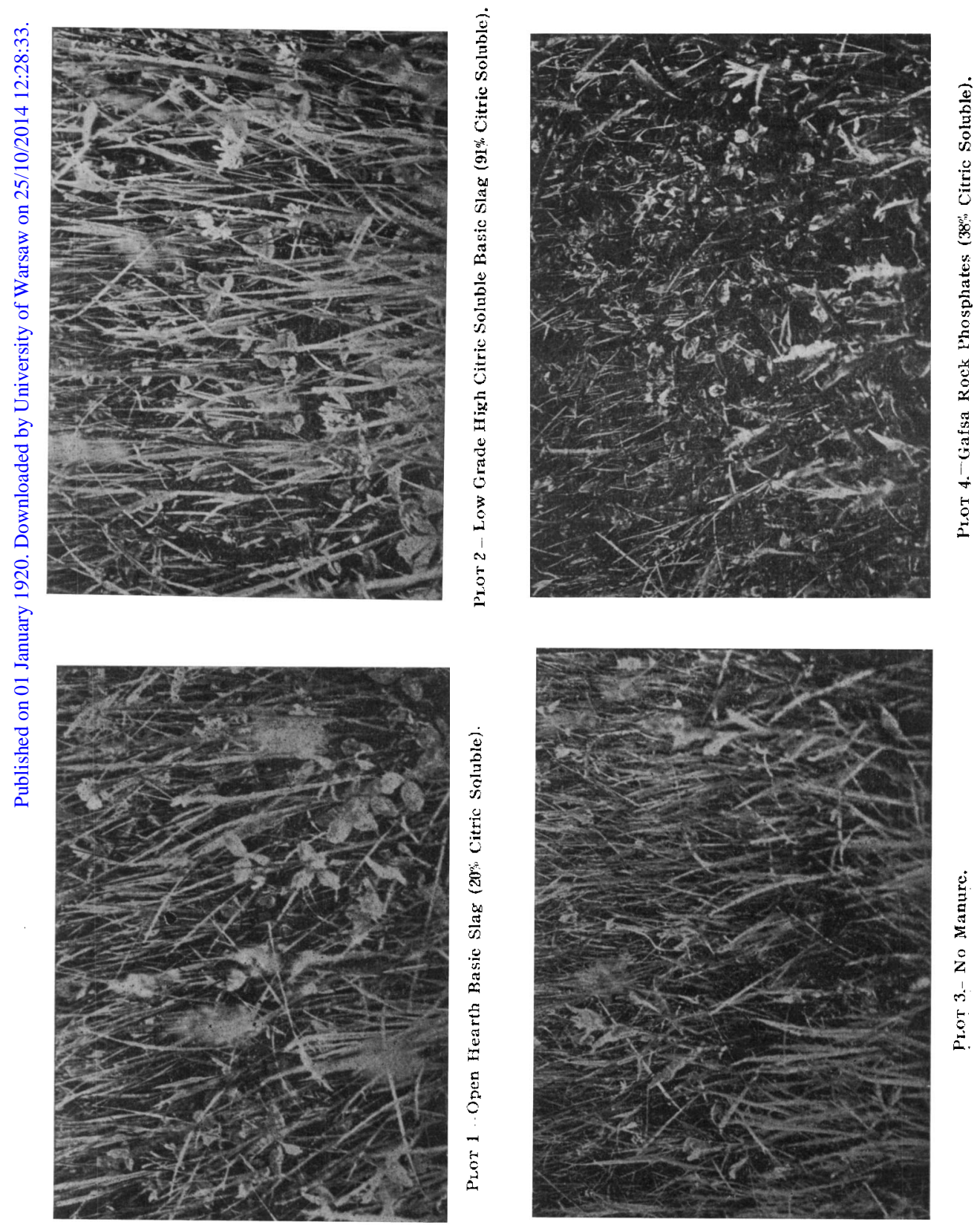

[? IG 1

(Photographs taken June, 1918.) 